\title{
Mesenteric arteriovenous fistula after a gunshot wound
}

Harold W. Forbes

University of Nebraska Medical Center

This manuscript is historical in nature and may not reflect current medical research and practice. Search PubMed for current research.

Follow this and additional works at: https://digitalcommons.unmc.edu/mdtheses

Part of the Medical Education Commons

\section{Recommended Citation}

Forbes, Harold W., "Mesenteric arteriovenous fistula after a gunshot wound" (1969). MD Theses. 88. https://digitalcommons.unmc.edu/mdtheses/88

This Thesis is brought to you for free and open access by the Special Collections at DigitalCommons@UNMC. It has been accepted for inclusion in MD Theses by an authorized administrator of DigitalCommons@UNMC. For more information, please contact digitalcommons@unmc.edu. 
MESENTERIO ARTERIOVENOUS FISTULA AFIER A GUNSHOT WOUND

\author{
Harold W. Forbes, B.S. \\ Choster Q. Thompson, M.D. \\ John W. Smith, M.D.
}

From the Department of Surgery, University of Nebraska college of Medicine, Omaha.

Reprint requests to 3610 Dodge St., Omaha, Nobraska 68131 (Dr. Smith). 


\section{THE JOURNAL OF TRAUMA}

SPONSORED BY THE AMERICAN ASSOCIATION FOR THE SURGERY OF TRAUMA

WnuaM T. FrTs, JR, M.D.

Hospital of the University of Pennsylvania Philadelphia, Pennsylvania 19104

December 19, 1968

Mr. Harold W. Forbes

Department of Surgery

University of Nebraska

College of Medicine

Omaha, Nebraska

Dear Mr. Forbes:

We are pleased to accept your paper, "Mesenteric Arteriovenous Fistula after a Gunshot Wound," for publication in The Journal of Trauma. It has been reviewed and approved by two editorial consultants, in keeping with our policy.

You should receive galley proofs within a few months. These should be correct and returned to us promptly, together with the original redacted manuscript.

With all good wishes,

WTF/ptb

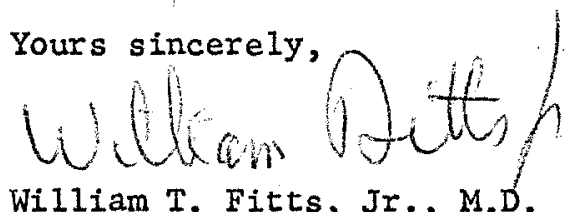

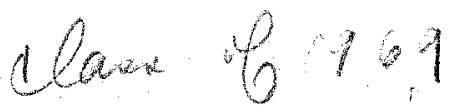


WESENTERIO ARTERTOVENOUS FISTULA ARTER A GUNSHOT WOUND

Harold W. Forbes, B.S., Ohester Q. Thompson, M.D., and John W. Smith, M.D.

An arteriovenous fistula; by the very fact that it is an abnormal interruption in the vascular system, has illuninated various physiological principles. It has demonstrated such effects as increased cardiac output, increased blood flow, congestive failure and recently has substantiated sore of the work done on atherosclerosis.

This vascular anomaly has been knom for over 200 years with the description in 1757 by William Hunter of a brachial artery basilic vein "anastomosis" secondary to the surgical procedure of "bleeding". They have been described in numerous locations throughout the vascular tree but only recently have fistulas involving the portal system been reported. These fistulas between the mesenteric vessels have been quito race with only 11 previously reported in the literature. This is a report of the twelfth case and a review of complications possible with this type of arteriovenous fistula.

\section{Case Report}

J.H. (360146) entered Methodist Hospital in Omaha on February 24, 1966, following a 22 caliber gunshot wound to the abdomen. At operation about $1000 \mathrm{ml}$ of blood was 
found in the abdomen. There was a toar at the bese of the saall mesentery which wa blooding. Thero was a large hemetoma wint the mesontery extending to the retroporitoneal tissues on the right. The blood olots were evecusted, and the bleeding from the sma11 bonel mesentery was stopped whth ingatures.

Ten days later on Maroh 6,1966 , the patient was agein operated on for drainage of a rotroporitoneal abscess. Whis and other abscesses were dratned, and muerous adhesions were lysed. On March 30, 1966, a thind oporation was perfoned because of snall bovel obstruction, fecal Pistula, a posible arteriovenons fistuia and posible Eangrene of the bowel. A thridl in the region of the mall bowel mesentery was notad at the previous operstion but was not present at this time. In addition, there vas a very large pelvic abscess which oocluded the simoid colon caveing obstruction and a fistuiou tract extending from the posterior aspect of the hepatio flexuremedially to the cscending colon and then out through a atab wound in the right flank. The teminal soveral feet of small bowel were of questionable viability. Al tho various abscesses were evacuated, and the tempinal one third of the smell intestine and the right colon were resected. An end-to-end anastomosis between ileum and midtranswerse colon was performed. The patient recovered and was dischered. 
Mbout two yeari later, the patient experienced an intermittent burning pain to the right of the umbilicus lagting only four or five days. He bad had diarrhea about three to five times per day since his previous hospitalization, but did not have any other gastrointestinal syraptoms. The patient was adntted to Douglas County Hopptai in Omahe on January 24, 1968. On physical examInation the patient was a vel-developed, well-nourished 23 year-old wan in no ecute distass. "Blood pressure was $148 / 90$, pulso was 60 per minute. Whore was a vortion midine abdoninel scar. BoweI sound nere nomad. There was a contimous machinexy type rarmur wath systolio accentuation over nost of the abroren but loudest above and to the right of the unbildous. A thrill was felt in this area also. Peripheral pulsea were prosent and equal bilaterajly. Laboratory data on admission Homoglobin 12.7 ga por $100 \mathrm{mi}$, hematocnt $42 \%$, white cell count 13,500 with a nomel differental, blood wrea nitrogen $13 \mathrm{mg}$ por $100 \mathrm{ml}$, urine andysis wath nomal limits, negative serology. The chest the shored possible viral pneumonitis on the right and a cardac disneter of 138 man which was about $15 \%$ greater than at his previous admission about two years ago. A retrogrede femoral aortogram showed early filing of tho portal system and some dilatod menenteric veins $(F i g, 1)$. 
On Fobruary 1, 1968, the patient was oporated on for a a a enteric axteriovonoug Estula. Exploration of the sbdomen revealed a prominent bmit which sppeared to be Et the base of the swall bowal rasentery $(F i g, 2)$. The fistula was between jejunel branch of the superior wesenterie artery and one of the nejor tabutaries of the superior taesenteric vein. Thers was a saculation on the venous sido appoximotely 2 on in dineter. With all the branohes of the shunt Individualy controlied and oonstricted, a period of observation mas matinined to observe whether or not the bowel would becone ischemic. Becouse there appeared to be very adoquate collateral circulation it was decidod to excise the fistula without reaction of any bovel. Tho pothological report deacribed the vein of the arteriovarous fistula to have a thickened weil due to hypertrophy of the nusele. The patient's postoperative course was uneventful, and he was dismigsed on February 9, 1968. His bovel habjts heve not changed, and he continues to have 200 se stools two to four times per day. At five months postoperatively ho has retumed to his job as a laborer for the city and has ganed ten pounds. The abcominal pain has not reourred.

Dincussion

This is the twelpun doomented oase of a mesenteric arteriovenous fistula $a^{2-12}$ (Table 1). Dent fistulas 
developed following gastrio or bonol resection, and four, including this case, were caused by a gushot wound. Athough this patient also had a bovel reseotion, a probabie fistula was diagnosed at the second operation prior to tho bowel resection. The thrili could not be felt at the third operation, and it was thought that the jotula had thrombosad. There have been fow sertous complicanons of mesenteric arteriovenous ristulas beouso of eariy ajagnosis (average 18 months) and treatrent, but from work done on other ristules it is likely thet these condd develop serious sequelae arter several years. As thom in artoriovenous fistulas outside the portal aystan, an increasing cordiec output snd blood volune causes cardiac distation and hypertropiy and oventualiy congestive heart falurel3,ith. In the presence of a fistula of large size and of considerable return flow of blood to the rioht stade of the hedt, electrocardiograms have show inconplete night bunde branch block ${ }^{15}$. Marked venous collaterel circulation with venous stasis is seen with most if not all types of istulas ${ }^{16}$.

Mesenteric arteriovenous istulas may in time lead to portal hypertension and the complications of ascites ${ }^{17}$, esophaged varicos ${ }^{18}$, and duodenal varices ${ }^{19}$. There has not yet been a case of congestive hoat failure developing from an arteriovenous fistula in the portal system. This tyoe of fistula is different frow the usual typo in that 
the high resistance venous sinusoidal systen of the liver lies between the fistula and the right heart ${ }^{17}$, and this apparently takes the place of the peripheral vasculature (arterioles).

The symptous associated with a mesenteric arteriovenous fistula are rather nonspecific. The most common complaints were vague abdoninal pain and mild diarrhea. Three of the 12 patients felt an abcominal thrill. This vague pain is most likely due to transient ischemic episodes in the area of the bovil served by the artery involved in the fistula. This parallels the findings of Koskinen and others that the tissue perfusion is decreased in the extremity distal to an axteriovonous fistula 20 .

There was evidence of markedly dilated veins on the arteriogram and this was subsequently borne out at the operation. This is also true in an extremity distal to a fistula ${ }^{20}$. In recent work done by stehbens 21 , it was show that the proximal artery of an arteriovenous fistula increased in size and developed a large fusiform dilatation both proximally and distally with much tortuosity and a thickened wall. These and other changes were consistent with degenerative changes in veins. These arteriosclerotic changes, although very sinilar to aging, were the result of altaced hemodynamics. 


\section{Suminary}

This is a report of the twelfth case of a mesenteric arteriovenous fistula with diagnosis by aortography and successful surgical treatment. As with all arteriovenous Pistulas there is the possibility of serious caraiovascular manifestations, but because of its location in the portal system and early diagnosis and treatment, these types of complications have been avoided. 
Table 1

Sumary of Mesenteric Arteriovenous Fistulas

ENIOLOGY LENGIH OF SURVIVAL PRESENTING COMPLAINT

TIME PRESENT

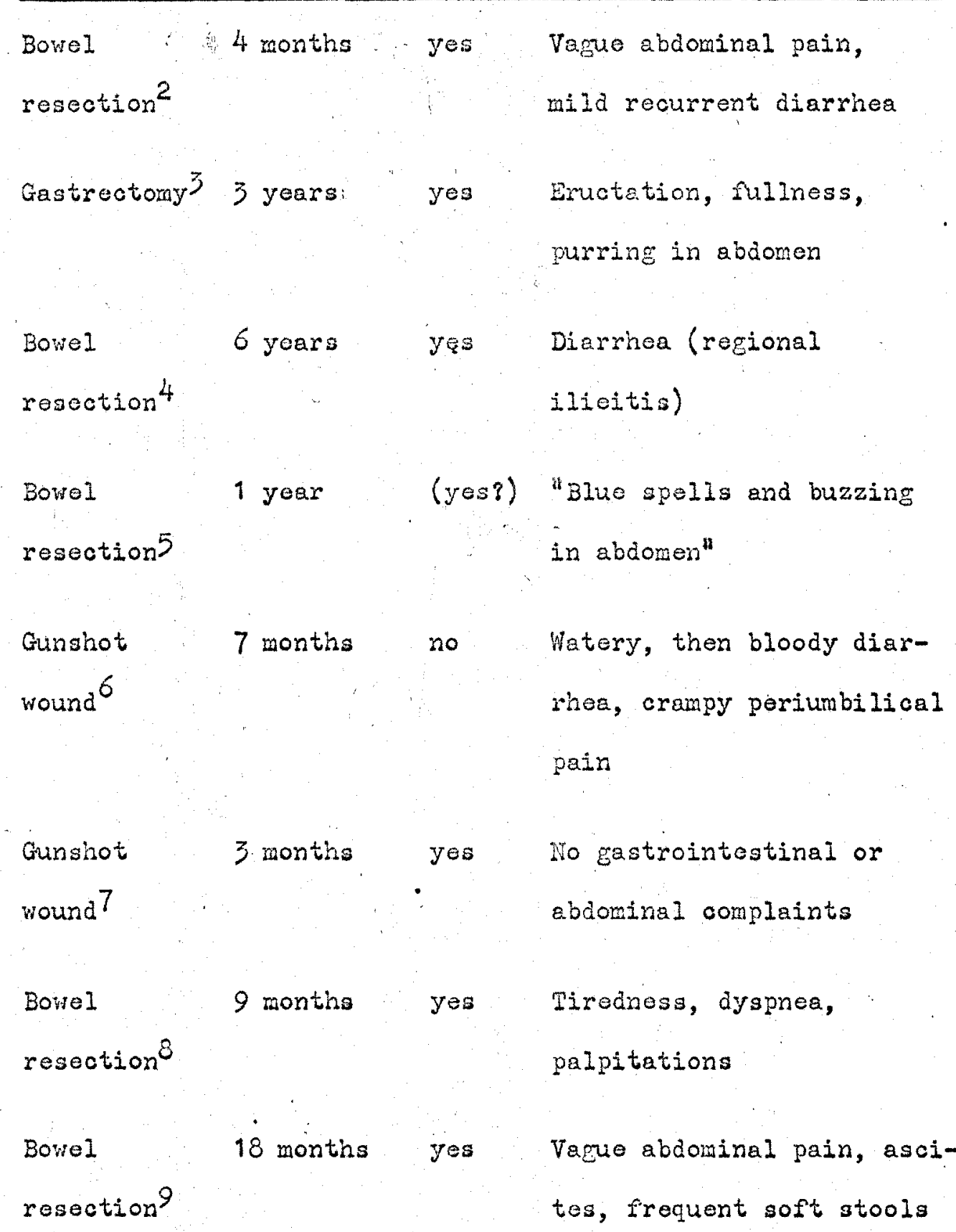




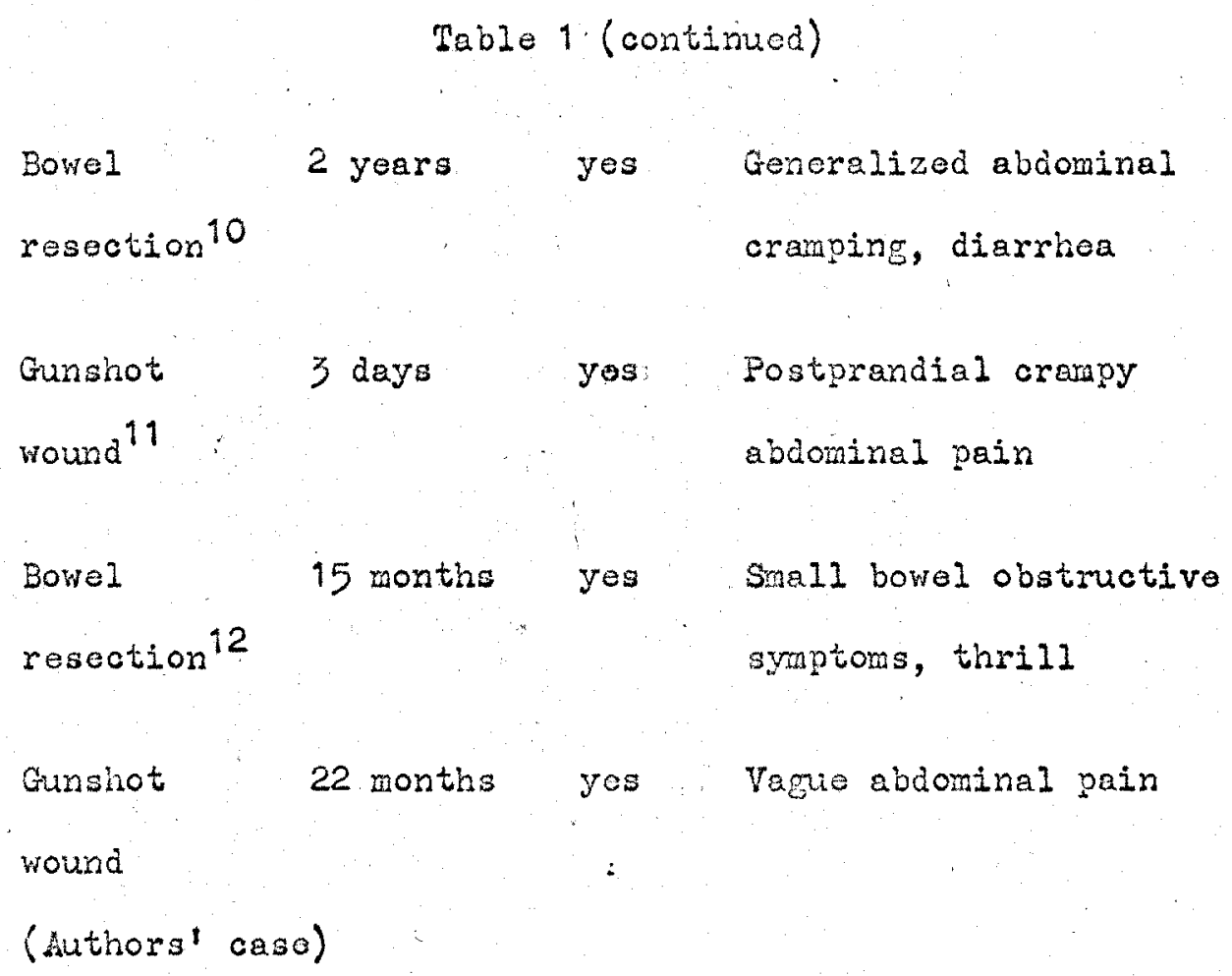




\section{Logends:}

Fig. 1. Aortogram domonstrating a well-outlined portal vein within three seconds after injection. The abnormal vessel pattern in the left lower quadrant is consistent with dilated and tortuous veins. Fig. 2. Site of the arteriovenous fistula. 


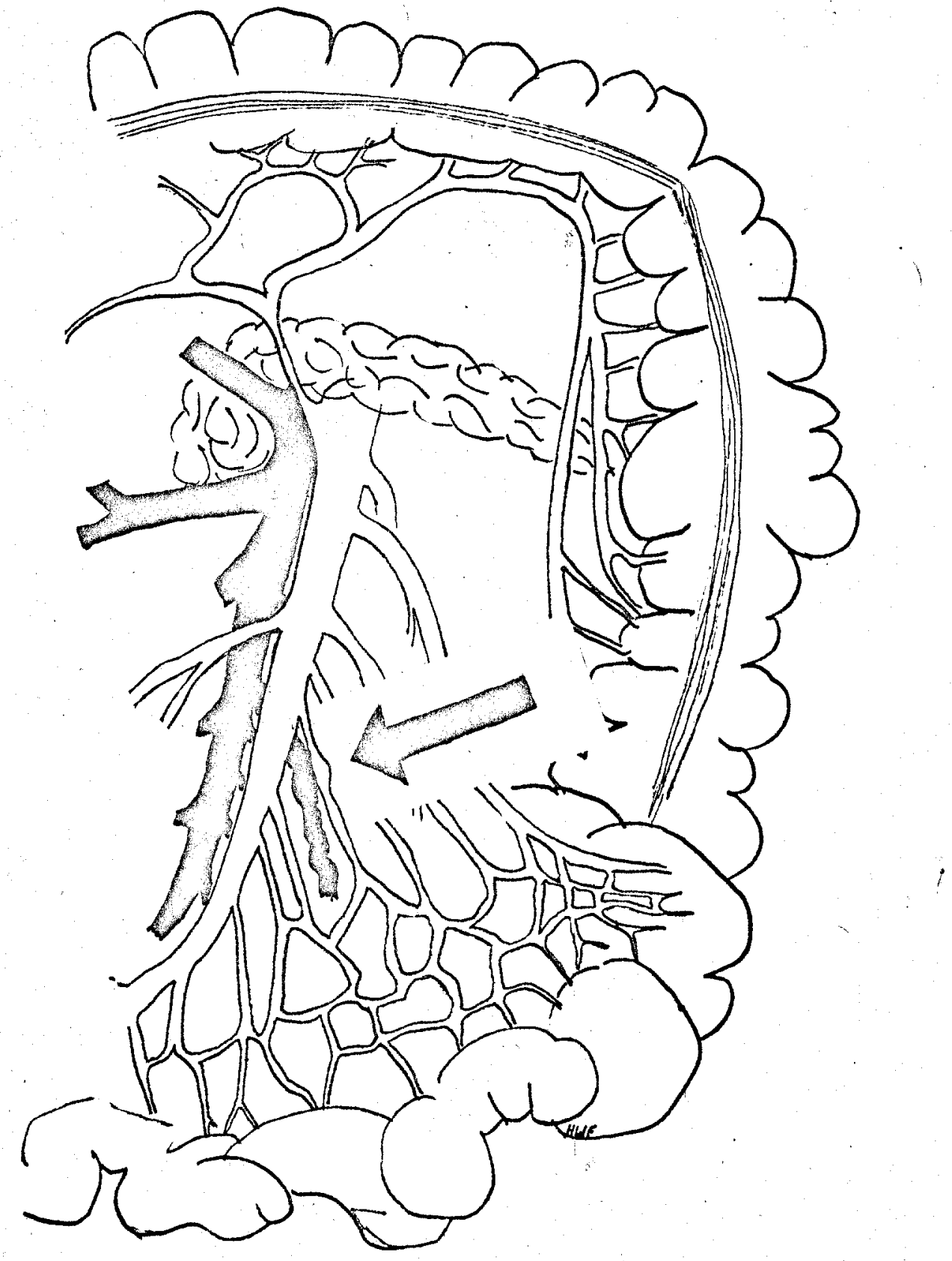




\section{REFERENCES}

1. Hunter, W.: The History of an Meurysm of the Aorta, with some Remarks on Aneurysms in general, Med Obs Inq $1: 323-3571757$

2. Movitz, D., and Finne, B.: Postoperative Arteriovenous Aneurysm in Mesentery after Sneil Bovel Resection, J a M A 173:42-44 (May 7) 1960 .

3. Rean, G.B.: A Middle Colic Arteriovenous Fistula Developing as a Postgastrectomy Complication, Arch Surg $81: 757-760$ (Nov.) 1960 .

4. Munnel1, E.R.; Mota, C.R.; and Thompson, W.B.: Iatrogenic Arteriovenous Fistula: Report of a Case Involving the Superior Mesenterio Vessels, Amer Surg 26:738-744 (Nov.) 1960 .

5. Durhara, M.W., et al: Arteriovenous Fistula of tho Mesenteric Vessels, Westorn J Surg 70:9-11 (Jan.-Feb.) 1962.

6. Rabhan, N.B.; Guillebeau, J.G.; and Brackney, E.L.: Arteriovenous Fistula of the Superior Mesenteric Vessels after a Gunshot Wound, New Eng J Med 266:603-605 ty (March 22) 1962.

7. Sumnor, R.G., et al: Rocognition and Surgical Repair of Superior Mesenteric Arteriovenous Fistula, Oirculation $27: 943-950$ (May) 1963.

3. Taylor, R.M.R., et al: Traumatic Fistula Between a Main Branch of the Superior Mesenteric Artery and Vein, Amer $\mathrm{J} \operatorname{Mod} 38: 641-645$ (April) 1965 
9. Grafe, W.R., and Steinberg, I.: Superior Mesenteric Arteriovenous Fistula Following Snall Bowel Resection, Gastroenterology 51:231-235 (Lug.) 1966 .

10. Gurrin, J.F., and Metcalf, B.H.: Postcolectomy Arteriovenous Fistula, Aner J Gasteroent 46:352-355 (0ct.) 1966.

11. Spellman, M.W., et al: SuccessfuI Repair of an Arteriovenous Fistula between the Superior Mesenteric Vessels Secondary to a Guashot Wound, Am Surg 165:458-463 (March) 1967.

12. Ganshirt, I.W.; Weaver, F.E.; and Olander, G.A.: Mesenteric Arterio-venous iFistula: Review of the Literature and a Report of a Case, Vasc Surg 1:82-86 (June) 1967.

13. Holman, E.: Abnomal Arteriovenous Communications: Great Variability of Effects with Particular Reference to Delayed Development of Cardiac Failure, Circulation 32:1001-1009 (Dec.) 1965.

14. Muenster, J.J.; Graettinger, J.S.; and Campbell, J.A.: Correlation of Olinical and Hemodynamic Findings in Patients with Systemic Arteriovenous Fistules, Oirculation 20:1079-1086 (Dec.) 1959.

15. Morim, D. de S., and Burchell, H.B.: The ElectrocardioGram in Systemic Arteriovenous Fistulas, Cardiologia $38: 319-3341961$.

16. Hillman, W., et al: Hemodynamic Changes of Arteriovenous Fistula Demonstrated by Arteriography, Surg Forum 10:476-480 1959. 
17. Foster, J.H., and SandbIom, P.: Portal Hypertension Secondary to an Hepato-Portal Arteriovenous Fistula, Ann Surg 154:300-304 (Aug.) 1961.

18. Madding, G.P.; Smith, W.L.; and Hershberger, L.R.: Hepatoportal Arteriovenous Fistuia, J A A 156:593-596 (oct.9) 1954.

19. Wheeler, H.B., and Warren, R.: Duodenal Varices Due to Portal Hypertension from Arteriovenous Aneurysm: Roport of a Case, An Surg 146:229-238 (Aug.) 1957.

20. Koskinen, E.V.S.; Tala, P.; and Siztanen, P.: The Effect of Massive Arteriovenous Histula on Hemodynamics and on Bone Growth: An Experimental Study on Dogs, Clin Orthop 50:309-319 (Jan.-Fob.) 1967 .

21. Stehbens, W.E.: Blood Vossel Changes in Chronic Experimental Arterioveoous Fistules, Surf Gynec Obstet 127:327-338 (sug.) 1968 